\title{
Gambaran perilaku seksual pada remaja
}

\author{
Lukman Candra Purnama, Aat Sriati, Indra Maulana*
}

Fakultas Keperawatan, Universitas Padjadjaran, Indonesia. *Email: indra.maulana@unpad.ac.id

\section{Abstract \\ Sexual behavior among high school students}

Background: Sexual behavior in adolescents indicates vulnerability to the incidence of venereal disease if the activity continues or leads to worse and even causes HIVIAIDS. Reasons for researchers take sample in high school students at Garut, its consideration is, based on the results of preliminary studies conducted by interviewing shows that some of the students' had a suspect negative sexual behavior.

Purpose: To describes of sexual behavior among high school students.

Method: The descriptive a quantitative with population all high school student and used stratified random sampling taken 268 respondents, univariate data analysis by descriptive analysis.

Results: Shows that less than half of sexual behavior among adolescents had risk categories of 100 respondents $(37.3 \%)$. In demographic data is similar to other studies that at the age of 16 years old, they have a sexual deviations behavior (compulsive or destructive).

Conclusion: The sexual behavior among high school students shows that there are still many teenagers who engage in risky sexual behavior. This required intervention to provide health education to students and expecting to reduce deviant sexual behavior.

\section{Keywords: Behavior; Sexual; High school; Students}

Pendahuluan: Perilaku seksual pada remaja mengindikasikan kerawanan terhadap kejadian penyakit kelamin jika kegiatan tersebut berlanjut atau mengarah kepada yang lebih buruk bahkan sampai menyebabkan HIVIAIDS Alasan peneliti mengambil tempat penelitian di SMAN X Garut Pertimbangannya adalah, berdasarkan hasil study pendahuluan yang dilakukan peneliti dengan cara memwawancarai siswa yang menunjukkan bahwa beberapa perilaku siswa sudah menjurus kearah perilaku seksual walaupun proporsinya masih dalam skala kecil.

Tujuan: Untuk mengetahui gambaran perilaku seksual remaja di SMAN X Garut.

Metode: Penelitian deskriptif kuantitatif dengan teknik pengambilan sempel yang digunakan yaitu stratified random sampling dengan strata diambil tiap kelas yang berjumlah 22 kelas. jumlah sampel sebanyak 268 orang dengan tehnik probability sampling terdiri dari perempuan dan laki-laki instrumen yag digunakan menggunakan instrumen yang sudah baku. Analisa data yang dilakukan secara univariat dengan analisis deskriptif.

Hasil: Menunjukan perilaku seksual pada remaja kurang dari setengahnya memiliki kategori berisiko sebanyak 100 remaja $(37,3 \%)$. Pada data demografi hasilnya sejalan dengan penelitian lain bahwa umur 16 tahun banyak terjadi penyimpangan seksual.

Simpulan: Perilaku seksual pada remaja di SMAN X Garut menunjukan masih banyak remaja yang yang melakukan perilaku seksual berisiko. Diperlukan intervensi untuk memberikan pendidikan kesehatan kepada siswa adn diharapkan dapat mengurangi perilaku seksual yang menyimpang.

\section{Kata kunci: Perilaku; Remaja; Seksual; Menyimpang}

\section{PENDAHULUAN}

Masa remaja merupakan salah satu fase penting bagi perkembangan pada tahap-tahap kehidupan selanjutnya. Dan berdasarkan sensus penduduk tahun 2000, jumlah remaja di Indonesia adalah 62.594 .200 jiwa atau sekitar $30,41 \%$ dari total seluruh penduduk Indonesia Dirjen P2PL dan

remaja adalah penduduk dalam rentang 10-18 tahun (Ayu, Nadiyah, Situngkir, \& Nitami, 2020; Kementerian Kesehatan Republik Indonesia, 2012; Azinar, 2013; Kementerian Kesehatan Republik Indonesia, 2014).

Diperkirakan jumlah kelompok remaja sekitar 1,2 milyar atau $18 \%$ dari jumlah penduduk dunia. 
Sedangkan di Indonesia jumlah penduduk usia 1019 tahun sebanyak 43,5 juta atau sekitar $18 \%$ dari jumlah penduduk (sensus penduduk 2010).dan menurut statistik pemuda Indonesia, pada tahun2014 sekitar 24,53\% dari 252,04 juta jiwa penduduk Indonesia adalah remaja atau setara dengan 61,83 jiwa (World Health Organization, 2014; Rahmadani, Agushybana, \& Dharmawan, 2018). Tentunya ini dapat menjadi aset bagi bangsa jika remaja tersebut menunjukan potensi yang positif namun sebaliknya akan menjadi masalah jika remaja berperilaku negatif apalagi sampai terlibat kenakalan remaja. Sedangkan kondisi remaja di Indonesia dapat digambarkan sebagai berikut, pernikahan usia remaja, kehamilan tidak diinnginkan atau sering disebut "Tua Sebelum Waktunya", sex pra nikah, aborsi, HIVIAIDS, miras dan narkoba.

Berdasarkan hasil penelitian di dunia mengeluarkan persentase yang sangat tinggi tentang banyaknya remaja yang mengakses pornografi, diantaranya yaitu $87 \%$ di USA, $84 \%$ Australia, 98\% Swedia, 99\% Italia. Menurut hasil data penelitian di Indonesia KPAI pada tahun 2008 di 33 provinsi terdapat $97 \%$ remaja SMP dan SMA pernah menonton film porno dan berdasarkan hasil monitoring dan pengaduan bidang $\mathrm{ABH}$ KPAI (anak berhubungan dengan hukum komisi perlindungan anak Indonesia) tahun 2013 didapatkan persentase $90 \%$ anak pelaku kekerasan seksual didahului karena mengakses situs pornografi (Hadiati, \& Ahmad, 2016). Berdasarkan penelitian yang telah tahun 2009 dilakukan di empar kota (Jakarta, Medan, Bandung dan Surabaya) sebanyak $35,9 \%$ remaja melakukan seks pranikah. Tahun 2010 meningkat menjadi $56,9 \%$ remaja melakukan hubungan seks pranikah dengan sampel 3.006 responden usia dari 17 sampai 24 tahun sebanyak 20,9\% remaja hamil dan melahirkan sebelum menikah (Kementerian Kesehatan Republik Indonesia, 2015).

Berdasarkan data hasil survey komisi perlindungan anak Indonesia (KPAl), sebanyak $32 \%$ remaja usia 14-18 tahun di kota-kota besar di Indonesia pernah hubungan seks pra nikah. Dari survey KPAI diketahui bahwa salah satu pemicu utama dari perilaku remaja tersebut adalah melihat pornografi yang di akses di internet (Saputro, 2015). Perilaku seksual yang dilakukan remaja sekarang dapat berakibat buruk untuk masa kedepannya.
Beberapa wilayah lain di Indonesia seperti Surabaya $54 \%$ remaja wanita lajang telah kehilangan keperawanannya kemudian di Bandung sekitar 47\% dan Medan sebanyak 52\%. Angka tersebut merupakan hasil survei yang dilakukan oleh BKKBN selama tahun 2010, (Mesra, 2016).Besarnya angka seks pranikah yang terjadi di kalangan remaja di Indonesia menjadi sebuah ancaman yang cukup serius dan dapat menyebabkan kehancuran moral bangsa.Perilaku seksual adalah segala tingkah laku yang di dorong oleh hasrat seksual baik yang dilakukan sendiri, dengan lawan jenis maupun sesama jenis.Bentukbentuk tingkah laku ini bermacam-macam, mulai dari perasaan tertarik sampai tingkah laku berkencan, bercumbu, dan bersenggama (Sarwono, 2011; Khairunnisa, 2013) Objek seksualnya bisa berupa orang lain, orang dalam khayalan atau diri sendiri.

Adanya persepsi bahwa dirinya memiliki resiko yang lebih rendah atau tidak beresiko sama sekali yang berhubungan dengan perilaku seksual, semakin mendorong remaja memenuhi dorongan seksualnya pada saat sebelum menikah. Persepsi ini disebut persepsi vulner ability. Perilaku seksual pada remaja SMA tersebut mengindikasikan kerawanan terhadap kejadian penyakit kelamin jika kegiatan tersebut berlanjut atau mengarah kepada yang lebih buruk, penyakit tersebut diantaranya penyakit kutil kelamin (genital Warts), Gonorrhoea, Chlamydia, Urethritis, Sifilis, Herpes Genital, Trichomonas dan bahkan sampai menyebabkan HIVIAIDS (Verawaty, \& Rahayu 2012; Pujiningtyas, 2014). Adanya dampak dari perilaku tersebut menyebabkan mereka yang semula diharapkan menjadi subjek pembangunan justru akan menjadi beban dari pembangunan itu sendiri. Oleh sebab itu, dampak yang ditimbulkan oleh perilaku seksual remaja pranikah dan juga perilaku seksual remaja itu sebagai akar masalah yang harus segera diatasi.

Bentuk perilaku seksual seperti berpegangan tangan, ciuman kering, ciuman basah, berpelukan, berfantasi atau berimajinasi, meraba, masturbasi, petting dan oral seks (Duvall \& Miler, 2015; Khairunisa, 2013). Oleh karena itu hal tersebut menimbulkan bahaya dan kerusakan sebagai dampak perilaku seksual atau pergaulan bebas dan pergaulan bebas dilarang karena menyebabkan terjadinya perbuatan yang tidak terpuji bahkan akan berakhir dengan suatu yang lebih buruk. Pada umumnya remaja memiliki rasa

Lukman Candra Purnama, Aat Sriati, Indra Maulana*

Fakultas Keperawatan, Universitas Padjadjaran, Indonesia. *Email: indra.maulana@unpad.ac.id 
ingin tahu yang tinggi (high curiousity). Remaja cenderung ingin berpetualang menjelajah segala sesuatu dan mencoba segala sesuatu yang belum pernah dialaminya. Selain didorong juga oleh keinginan menjadi seperti orang dewasa menyebabkan remaja ingin mencoba melakukan apa yang sering dilakukan orang dewasa termasuk yang berkaitan dengan masalah seksualitas (Azwar, 2010; Azinar, 2013). Dalam penelitian mengungkapkan bahwa pada usia remaja rasa ingin tahu terhadap seks begitu besar. Apalagi jika teman sebayanya mengatakan bahwa seks itu nikmat, ditambah adanya legal informasi yang tidak terbatas. Dari situ rasa penasaran mereka semakin tinggi untuk melakukan berbagai macam percobaan sesuai dengan keinginannya.selain itu niat ini juga di pengaruhi oleh pihak-pihak terdekatnya, hal ini dikarenakan orang-orang terdekatnya juga melakukan hal yang sama bahkan remaja terkadang melakukan perilaku seks pra nikah dengan pihak-pihak tersebut seperti, teman dekat, teman kos dan teman sekomunitasnya. Hal ini menjadikan remaja semakin berani dan bebas serta merasa di dukung secara tidak langsung dalam berprilaku seks pranikah. Faktor- faktor yang mempengaruhi perilaku seksual pranikah pada remaja paling tinggi hubungan atara orang tua dengan remaja, diikuti karena tekanan teman sebaya, religiusitas, dan eksposur media pornografi (Soetjiningsih, 2010; Pantiawati \& Trisnawati, 2014).

Berdasarkan hasil studi pendahuluan yang di lakukan di SMAN X GARUT pada tanggal 11 Desember 2018 kepada 15 orang siswa dengan cara wawancara, dari 15 orang tersebut 10 orang berpacaran dan 5 orang tidak pacaran, 5 dari 10 orang siswa yang berpacaran pernah melakukan perilaku seksual seperti berpegangan tangan dan satu dari 5 orang siswa pernah berciuman, ada juga salah satu siswa mengatakan pernah melihat temannya melakukan perilaku seksual dan juga sesekali pernah melihat pornografi di internet. Saat ditanya bagaimana sikap siswa tersebut setelah melihat perilaku seksual di internet siswa tersebut mengatakan rasa ingin melakukan seks nya itu lebih tinggi dan bahkan sesekali pernah melakukan onani. saat wawancara dengan guru bimbingan dan konseling (BK) banyak yang melihat video pornografi itu terbukti saat guru BK melakukan razia handphone dan saat dilihat banyak sekali riwayat pencarian internet yang mengarah ke situssitus yang menjurus ke pornografi.

Alasan peneliti mengambil tempat penelitian di SMAN $X$ Garut Pertimbangannya adalah, berdasarkan hasil studi pendahuluan yang dilakukan peneliti dengan cara mewawancarai siswa yang menunjukkan bahwa beberapa perilaku siswa sudah menjurus kearah perilaku seksual walaupun proporsinya masih dalam skala kecil dan ini akan terus terjadi peningkatan. Secara geografis SMAN $X$ garut dekat dengan jalan raya dan sekitar 2 kilometer jarak ke tempat hiburan yang ada di Kota Garut yang merupakan tempat startegis yang mendukung faktor-faktor penyebab terjadinya perilaku seksual pada remaja, lebih lanjut peneliti juga belum memperoleh data spesifik pravalensi signifikan setiap tahunnya mengenai perilaku seksual pada remaja dari instansi terkait yang ada di Kabupaten Garut seperti Dinas kesehatan, bidang kesehatan Anak dan Keluarga dan Koordinasi Keluarga Berencana Nasional Kabupaten Garut.

\section{METODE PENELITIAN}

Penelitian ini menggunakan deskriptif quantitative, populasinya semua siswa siswi kelas XI dan Kelas XII di SMAN X Garut. Teknik sampel yang digunakan dengan metode stratified random sampling dan rumus slovin didapatkan sejumlah sampel 268 responden. Kuesioner yang diberikan sebanyak 13 pertanyaan dan dianalisis kedalam kategori beresiko jika responden menjawab 11 pertanyaan dari 13 pertanyaan karena no 9 dan no 13 tidak termasuk kedalam kategori perilaku berisiko pertanyaan dengan total nilai mean $\geq$ 14,56 dikategorikan beresiko dan dikategorikan perilaku tidak berisiko jika menjawab dengan total nilai mean $\leq 14,56$. 


\section{HASIL}

Tabel 1 Karakteristik Responden (N=268)

\begin{tabular}{ccc}
\hline Karakteristik & Frekuensi (f) & Persentase (\%) \\
\hline Usia & & \\
15 Tahun & 25 & 9.3 \\
16 Tahun & 133 & 49.6 \\
17 Tahun & 107 & 39.9 \\
18 Tahun & 3 & 1.1 \\
Jenis Kelamin & & \\
$\quad$ Laki-laki & 115 & 42.9 \\
Perempuan & 153 & 57.1 \\
Agama & & \\
Islam & 268 & 100 \\
Suku Bangsa & & \\
Sunda & & 96.6 \\
Jawa & 256 & 2.6 \\
Minang & 7 & 0.4 \\
Lainnya & 1 & 0.4 \\
Kelas $\quad 1$ & \\
$\quad$ XI & & 54.1 \\
XII & 145 & 45.9 \\
\hline
\end{tabular}

Berdasarkan Tabel 1 diatas, didapatkan data karakteristik demografi yang menunjukan hasil bahwa Usia responden sebagian besar 16 Tahun $(49,6 \%)$, berjenis kelamin perempuan $(57,1 \%)$, seluruhnya beragama islam $(100 \%)$. suku sunda $(96,6 \%)$ dan sebagian besar dari kelas XI $(54,1)$. 
Tabel 2. Pertanyaan Yang Berkaitan Dengan Perilaku Seksual

\begin{tabular}{|c|c|c|c|}
\hline Pertanyaan & Jawaban & Frekuensi (f) & Persentase (\%) \\
\hline Melihat film atau gambar porno & $\begin{array}{l}\text { Tidak pernah } \\
\text { Jarang } \\
\text { Sering } \\
\text { Selalu }\end{array}$ & $\begin{array}{l}129 \\
128 \\
7 \\
4\end{array}$ & $\begin{array}{l}48.1 \\
47.8 \\
2.6 \\
1.5\end{array}$ \\
\hline Mengakses atau membuka situs porno & $\begin{array}{l}\text { Tidak pernah } \\
\text { Jarang } \\
\text { Sering } \\
\text { Selalu }\end{array}$ & $\begin{array}{l}155 \\
109 \\
2 \\
2\end{array}$ & $\begin{array}{l}57.8 \\
40.7 \\
0.7 \\
0.7\end{array}$ \\
\hline Meraba bagian sensitif (dilakukan sendiri) & $\begin{array}{l}\text { Tidak pernah } \\
\text { Jarang } \\
\text { Sering } \\
\text { Selalu }\end{array}$ & $\begin{array}{c}231 \\
34 \\
3 \\
0\end{array}$ & $\begin{array}{c}86.2 \\
12.7 \\
1.1 \\
0\end{array}$ \\
\hline $\begin{array}{l}\text { Berpegangan tangan dengan pacar atau } \\
\text { lawan jenis yang disukai }\end{array}$ & $\begin{array}{l}\text { Tidak pernah } \\
\text { Jarang } \\
\text { Sering } \\
\text { Selalu }\end{array}$ & $\begin{array}{l}95 \\
129 \\
34 \\
10\end{array}$ & $\begin{array}{l}35.4 \\
48.1 \\
12.7 \\
3.7\end{array}$ \\
\hline $\begin{array}{l}\text { Berpelukan dengan lawan jenis yang } \\
\text { disukai }\end{array}$ & $\begin{array}{l}\text { Tidak pernah } \\
\text { Jarang } \\
\text { Sering } \\
\text { Selalu }\end{array}$ & $\begin{array}{l}195 \\
58 \\
13 \\
2\end{array}$ & $\begin{array}{l}72.8 \\
21.6 \\
4.9 \\
0.7\end{array}$ \\
\hline Mencium kening lawan jenis yang disukai & $\begin{array}{l}\text { Tidak pernah } \\
\text { Jarang } \\
\text { Sering } \\
\text { Selalu }\end{array}$ & $\begin{array}{c}221 \\
32 \\
14 \\
1\end{array}$ & $\begin{array}{l}82.5 \\
11.9 \\
5.2 \\
0.4\end{array}$ \\
\hline Mencium pipi lawan jenis yang disukai & $\begin{array}{l}\text { Tidak pernah } \\
\text { Jarang } \\
\text { Sering } \\
\text { Selalu }\end{array}$ & $\begin{array}{c}217 \\
41 \\
7 \\
3\end{array}$ & $\begin{array}{l}81.0 \\
15.3 \\
2.6 \\
1.1\end{array}$ \\
\hline $\begin{array}{l}\text { Melakukan ciuman di bibir dengan lawan } \\
\text { jenis yang disukai }\end{array}$ & $\begin{array}{l}\text { Tidak pernah } \\
\text { Jarang } \\
\text { Sering } \\
\text { Selalu }\end{array}$ & $\begin{array}{l}243 \\
21 \\
3 \\
1\end{array}$ & $\begin{array}{l}90.7 \\
7.8 \\
1.1 \\
0.4\end{array}$ \\
\hline $\begin{array}{l}\text { Risih jika melakukan ciuman dengan lawan } \\
\text { jenis yang disukai }\end{array}$ & $\begin{array}{l}\text { Tidak pernah } \\
\text { Jarang } \\
\text { Sering } \\
\text { Selalu }\end{array}$ & $\begin{array}{l}171 \\
26 \\
26 \\
45\end{array}$ & $\begin{array}{c}63.8 \\
9.7 \\
9.7 \\
16.8\end{array}$ \\
\hline $\begin{array}{l}\text { Meluangkan waktu untuk berduan dengan } \\
\text { lawan jenis yang disukai untuk melakukan } \\
\text { perilaku seksual }\end{array}$ & $\begin{array}{l}\text { Tidak pernah } \\
\text { Jarang } \\
\text { Sering } \\
\text { Selalu }\end{array}$ & $\begin{array}{l}239 \\
23 \\
2 \\
4\end{array}$ & $\begin{array}{l}89.2 \\
8.6 \\
0.7 \\
1.5\end{array}$ \\
\hline $\begin{array}{l}\text { Berkumpul dengan teman melihat video } \\
\text { porno }\end{array}$ & $\begin{array}{l}\text { Tidak pernah } \\
\text { Jarang } \\
\text { Sering } \\
\text { Selalu }\end{array}$ & $\begin{array}{c}196 \\
66 \\
2 \\
4\end{array}$ & $\begin{array}{c}73.10 \\
24.6 \\
0.7 \\
1.5\end{array}$ \\
\hline $\begin{array}{l}\text { Setelah melihat video, terangsang untuk } \\
\text { melakukannya sendiri (meraba bagian } \\
\text { sensitif) }\end{array}$ & $\begin{array}{l}\text { Tidak pernah } \\
\text { Jarang } \\
\text { Sering } \\
\text { Selalu }\end{array}$ & $\begin{array}{c}224 \\
41 \\
2 \\
1\end{array}$ & $\begin{array}{l}83.6 \\
15.3 \\
0.7 \\
0.4\end{array}$ \\
\hline $\begin{array}{l}\text { Risih jika diajak menonton video porno } \\
\text { oleh teman atau pacar }\end{array}$ & $\begin{array}{l}\text { Tidak pernah } \\
\text { Jarang } \\
\text { Sering } \\
\text { Selalu }\end{array}$ & $\begin{array}{l}86 \\
97 \\
41 \\
44\end{array}$ & $\begin{array}{l}32.1 \\
36.2 \\
15.3 \\
16.4\end{array}$ \\
\hline
\end{tabular}


Berdasarkan data tabel 2 tampak bahwa perilaku seksual pada remaja berdistribusi beresiko dengan persentase tertinggi pada pertanyaan no 9 mengenai risih jika melakukan ciuman dengan pacar dengan hasil nilai selalu 16,8\%, dan pertanyaan no 13 mengenai risih jika diajak nonton film porno oleh pacar dengan hasil nilai selalu $16,4 \%$. Sedangkan pada no 13 juga dengan hasil sering $15,3 \%$ dan pada no 4 mengenai berpegangan dengan pacar atau lawan jenis yang disukai dengan hasil nilai jarang 48,1\%, juga pada no 1 mengenai melihat gambar atau film porno dengan nilai hasil jarang $47,8 \%$.

Tabel 3. Perilaku Seksual Pada Remaja ( $\mathrm{N}=268)$

\begin{tabular}{lcc}
\hline Variabel & Frekuensi (f) & Persentase (\%) \\
\hline Berisiko & 100 & 37.3 \\
Tidak Berisiko & 168 & 62.7 \\
\hline
\end{tabular}

Berdasarkan hasil tabel 3 tampak bahwa perilaku seksual remaja berdistribusi berisiko kurang dari setengahnya $37,3 \%$ dan tidak berisiko lebih dari setengahnya yaitu $62,7 \%$.

\section{PEMBAHASAN}

Berdasarkan hasil penelitian menunjukan bahwa, perilaku seksual pada remaja didapatkan data karakteristik demografi yang menunjukan hasil bahwa penyebaran responden relatif pada usia 16 tahun sebanyak $133(49,6 \%)$, usia 17 tahun sebanyak $107(39,9 \%)$, usia 15 tahun sebanyak $25(9,3 \%)$ dan usia 18 tahun sebanyak $3(1,1 \%)$. Hal ini sejalan dengan penelitian sebelumnya dimana responden berada pada usia 14-18 tahun, usia terbanyak sebagian besar responden berumur 16 tahun (54,5\%) (Mahmudah, Yaunin, \& Lestari, 2016). Remaja yang berusia 1517 tahun merupakan usia remaja madya atau pertengahan. Remaja diusia pertengahan memiliki ciri khas terkait perkembangan fisik dan seksualnya. Remaja sudah mengalami pematangan fisik secara penuh, laki-laki sudah mengalami mimpi basah sedangkan perempuan sudah mengalami haid (Soetjiningsih, 2007; Pantiawati, \& Trisnawati, 2014). Secara seksual remaja pada masa ini memiliki keberanian untuk melakukan kontak fisik dengan lawan jenis (Pangkahila, 2015). Gaya berpacaran remaja pertengahan sudah mulai berpegangan tangan, berpelukan hingga sampai aktivitas seksual yang beresiko (Sarwono, 2011; Yanti, \& Dewi, 2015).

Sedangkan berdasarkan jenis kelamin responden menunjukan lebih dari setengahnya berjenis kelamin perempuan yaitu sebanyak 153 responden $(57,1 \%)$ dan berjenis kelamin laki-laki sebanyak 115 responden (42,9\%).Walaupun dalam penelitian ini hasil jenis kelamin perempuan lebih banayak tetapi, Jenis kelamin tidak berpengaruh terhadap perilaku seksual responden. $\mathrm{Hal}$ ini sejalan dengan penelitian sebelumnya bahwa jenis kelamin tidak berpengaruh dikarenakan adanya kecenderungan pergaulan yang semakin bebas antara laki-laki dan perempuan dalam masyarakat yang mengakibatkan kependudukan perempuan menjadi setara dengan laki-laki sehingga baik laki-laki maupun perempuan mempunyai peluang yang sama. Adanya perubahan zaman modernisasi serta majunya tingkat pendidikan perempuan yang berakibat melasnya peran perempuan kepada hal yang dulunya hanya dikerjakan oleh laki-laki juga mempunyai andil, menyebabkan meningkatnya keterlibatan perempuan dan laki-laki pada tindakan seksual (Hartnagel, \& Tanner, 1982; Kurniasari 2007; Amaliyasari, \& Puspitasari, 2008).

Sedangkan berdasarkan pertanyaan tentang perilaku seksual pada remaja tergambar pada tabel 2 menunjukan paling besar dalam perilaku seksual adalah berpegangan tangan dengan nilai $48,1 \%$, melihat gambar atau film porno dengan nilai $47,8 \%$. Walaupun nilai tertinggi berada pada no 1 dan 4 tetapi banyak juga yang melakukan perilaku seksual yang beresiko lainnya tidak menutup kemungkinan banyak responden yang cenderung mendekati perilaku seksual yang beresiko. Karena berpegangan tangan merupakan tahapan pertama dari perilaku seksual, pegangan tangan akan menimbulkan perasaan nyaman dan dapat menimbulkan rangsangan erotis walaupun pada awalnya kegiatan ini dilakukan dengan maksud untuk menunjukan perasaan sayang.

Berdasarkan hasil penelitian tentang perilaku seksual remaja tergambar pada tabel 3 menunjukan bahwa perilaku seksual yang beresiko yaitu $37,3 \%$ dan yang tidak beresiko yaitu $62,7 \%$. 
hal ini tidak sejalan dengan penelitian sebelumya bahwa perilaku seks pranikah pada remaja dalam kategori beresiko yaitu sebesar $62 \%$ dan yang tidak beresiko $38 \%$. Berdasarkan hasil penelitian menujukan tindakan negatif siswa menggambarkan pergeseran perilaku seksual kearah menyimpang (permisif) atau kearah perilaku seksual beresiko (Naja, Agusyahbana, \& Mawarni, 2017).

Dampak dari perilaku seksual beresiko diantaranya: dampak psikologis yang didapatkan oleh remaja adalah perasaan marah, takut, cemas, depresi, rendah diri, bersalah, dan berdosa, dampak fisiologis dari perilaku seks bebas adalah menimbulkan kehamilan tidak diinginkan dan aborsi, dampak sosial yang timbul adalah dikucilkan, putus sekolah pada remaja perempuan yang hamil, dan perubahan peran menjadi ibu serta tekanan dari masyarakat yang mencela dan menolak keadaan tersebut, dampak fisik dari perilaku seks bebas adalah berkembangnya penyakit menular seksual yang akan mengakibatkan kemandulan dan rasa sakit kronis serta meningkatkan risiko terkena HIVIAIDS (Lubis, 2013; Darnoto, 2016).

Perilaku merupakan konsepsi yang tidak sederhana atau kompleks dimana dipengaruhi oleh faktor internal seperti emosi, motivasi, dan persepsi. Kemudian dipengaruhi pula oleh faktor eksternal seperti pergaulan, budaya, kondisi sosialekonomi, dan sebagainya (Haryanto, \& Suarayasa, 2013).

Faktor-faktor yang mempengaruhi perilaku seksual pada remaja. antara lain: faktor internal (pengetahuan, aspek-aspek kesehatan reproduksi, sikap terhadap layanan kesehatan seksual dan reproduksi, perilaku, kerentanan yang dirasakan terhadap resiko, kesehatan reproduksi, gaya hidup, pengendalian diri, aktifitas sosial, rasa percaya diri, usia, agama, dan status perkawinan), faktor eksternal (kontak dengan sumber-sumber informasi, keluarga norma sebagai pendukung sosial untuk perilaku tertentu (Suryoputro, Ford, \& Shaluhiyah, 2006; Darnoto, 2016).

\section{SIMPULAN}

Berdasarkan analisa hasil penelitian dan pembahasan tentang gambaran perilaku seksual pada remaja di SMAN X Garut kepada 268 responden yang disajikan dengan dibagi kedalam dua kategori, yaitu kategori perilaku seksual yang beresiko dan perilaku seksual yang tidak beresiko.
Dapat dapat ditarik kesimpulan bahwa gambaran perilaku seksual pada remaja di SMAN X Garut kurang dari setengahnya memiliki kategori perilaku seksual yang beresiko $(37,3 \%)$, dan lebih dari setengahnya memiliki kategori perilaku seksual yang tidak beresiko $(62,7 \%)$.

\section{DAFTAR PUSTAKA}

Amaliyasari, Y., \& Puspitasari, N. (2008). Perilaku seksual anak usia pra remaja di sekitar lokalisasi dan faktor yang mempengaruhi. Jurnal Penelitian Dinas Sosial, 7(1), 54-60.

Ayu, I. M., Nadiyah, N., Situngkir, D., \& Nitami, M. (2020). Program peningkatan pengetahuan kesehatan reproduksi remaja di SMK " $X$ " Tangerang Raya. Jurnal Kreativitas Pengabdian Kepada Masyarakat (PKM), 3(1), 87-95.

Azinar, M. (2013). Perilaku seksual pranikah berisiko terhadap kehamilan tidak diinginkan. KEMAS: Jurnal Kesehatan Masyarakat, 8(2).dari https:/journal.unnes.ac.id/nju/index.php/kemas/ article/view/2639

Azwar, A. (2010). Kesehatan Reproduksi Remaja di Indonesia (Adolescent Reproductive Health in Indonesia). In unpublished paper presented at the: National Congress of Epidemiology IX in Jakarta (Vol. 8).

Darnoto, A. R. P. (2016). Hubungan penggunaan Smartphone Dengan Perilaku Seksual Remaja Di SMAN “ $X$ ” Jember.

Duvall, E. R. M., \& Miller, B. C. (2010). Marriage and family development (15th Ed). New York: Harper \& Row Publisher.

Hadiati, I. D. T., \& Ahmad, H. S. (2016). Hubungan pengaksesan situs pornografi dengan sikap seksual pranikah pada remaja di SMA 2 Banguntapan Bantul Yogyakarta (Doctoral dissertation, Universitas' Aisyiyah Yogyakarta). 
Hartnagel, T. F., \& Tanner, J. (1982). Class, Schooling and Delinquency: A Further Examination. Canadian J. Criminology, 24, 155.

Haryanto, R., \& Suarayasa, K. (2013). Perilaku seksual pranikah pada siswa SMA Negeri 1 Palu. Academica, 5(2).

Kementerian Kesehatan Republik Indonesia. (2012). Survei Demografi dan Kesehatan Indonesia 2012 Kesehatan Reproduksi Remaja. Diakses dari: http://kesga.kemkes.go.id/images/pedoman/SD KI-2012-Remaja-Indonesia.pdf

Kementerian Kesehatan Republik Indonesia. (2014). Peraturan Menteri Kesehatan Republik Indonesia Nomor 25 Tahun 2014 Tentang Upaya Kesehatan Anak. Diakses dari: http://kesga.kemkes.go.id/images/pedoman/PM K\%20No.\%2025\%20ttg\%20Upaya\%20Kesehat an\%20Anak.pdf

Kementerian Kesehatan Republik Indonesia. (2015). Situasi Kesehatan Reproduksi Remaja. Diakses dari: https://pusdatin.kemkes.go.id/article/view/1509 0700003/situasi-kesehatan-reproduksiremaja.html

Khairunnisa, A. (2013). Hubungan religiusitas dan kontrol diri dengan perilaku seksual pranikah $\begin{array}{lll}\text { remaja di } & \text { MAN }\end{array}$ Samarinda. Psikoborneo, 1(3).

Kurniasari, D. M. (2007). Faktor yang mempengaruhi perilaku seksual di kalangan mahasiswa: Studi Pada Mahasiswa Universitas Airlagga Surabaya (Doctoral dissertation, Universitas Airlangga).

Lubis, N. L. (2013). Psikologi Kespro Wanita dan Perkembangan Reproduksinya. Jakarta: Kencana.

Mahmudah, M., Yaunin, Y., \& Lestari, Y. (2016). Faktor-faktor yang berhubungan dengan perilaku seksual remaja di Kota Padang. Jurnal Kesehatan Andalas, 5(2).
Mesra, E. (2016). Pengaruh Teman Sebaya Terhadap Perilaku Seksual Remaja, (2).

Naja, Z. S., Agusyahbana, F., \& Mawarni, A. (2017). Hubungan pengetahuan, sikap mengenai seksualitas dan paparan media sosial dengan perilaku seksual pranikah pada remaja di beberapa SMA kota Semarang triwulan II tahun 2017. Jurnal Kesehatan Masyarakat (eJournal), 5(4), 282-293.

Pangkahila, W. (2015). Peranan seksuologi dalam kesehatan reproduksi. dalam: Obstetri dan Ginekologi Sosial. Yayasan Bina Pustaka Sarwono. Jakarta. Hal, 64-70.

Pantiawati, I., \& Trisnawati, Y. (2014). Faktor-Faktor Yang Berhubungan Deng Seks Pranikah Pada Remaja Di Desa Susukan Kecamatan Sumbang. Bidan Prada: Jurnal Publikasi Kebidanan Akbid YLPP Purwokerto, 5(1).

Pujiningtyas, L. R. (2014). Hubungan penggunaan media sosial dengan perilaku seks siswa smp di surakarta artikel publikasi ilmiah, 0-16.

Rahmadani, I., Agushybana, F., \& Dharmawan, Y. (2018). Hubungan Persepsi Lingkungan Tempat Tinggal Dan Pemanfaatan Smartphone Dengan Perilaku Berpacaran Yang Beresiko Pada Remaja Yang Tinggal Di Daerah Lokalisasi Gambilangu Kota Semarang, 6(1).

Saputro, A. (2015). Perilaku Seks Pranikah Mahasiswa Pengguna Jasa Cybersex Di Kota Semarang, 3(April), 851-859.

Sarwono, S. W. (2015). Psikologi Remaja edisi revisi. Jakarta: Rajawali Pers.

Soetjiningsih, P. (2010). Dr. SpA (K), IBCLC (penyunting) dalam Tumbuh Kembang Remaja dan Permasalahannya. Cet. 5.

Suryoputro, A., Ford, N. J., \& Shaluhiyah, Z. (2006). Faktor-faktor yang mempengaruhi perilaku seksual remaja di jawa tengah: implikasinya terhadap kebijakan dan layanan kesehatan seksual dan reproduksi. Makara kesehatan, 10(1), 29-40. 
Gambaran perilaku seksual pada remaja

Verawaty, S. N., \& Rahayu, L. (2012). Merawat dan menjaga kesehatan seksual wanita. Bandung: Gravindo, 46-55.

World Health Organization. (2014). Health for the World's Adolescents A second chance in the second decade. Diakses dari: https://apps.who.int/adolescent/seconddecade/files/1612_MNCAH_HWA_Executive_S ummary.pdf
Yanti, E. D., \& Dewi, Y. I. (2015). Pengaruh pendidikan kesehatan dengan menggunakan media audiovisual terhadap pengetahuan dan sikap remaja mengenai upaya pencegahan penyakit menular seksual (Doctoral dissertation, Riau University). 